\title{
İlkokul Dördüncü Sınıf Öğrencilerinin Okuma Motivasyonlarını Etkileyen Faktörlere İlişkin Görüşleri
}

\section{The Views of 4th Grade Students on the Factors Affecting Reading Motivation}

Nurullah KARAKULLUKÇU ${ }^{1}$ Yaşar ÇELİ ${ }^{2}$

Makale Hakkında
Gönderim Tarihi:23.04
Kabul Tarihi: 26.09.202
Yayın Tarihi: 01.11.202
Anahtar Kelimeler
İlkokul,
okuma,
motivasyon, okuma
motivasyonu

Key Word

Primary school, reading, motivation, reading motivation

\begin{abstract}
$\ddot{O}_{z e t}$
Okuma, bireylerin günlük yaşamında kullandıkları temel becerilerden biridir. Okuma göz, ses ve beynin çeşitli fonksiyonlarının birlikte çalıştığ karmaşık bir süreçtir. Yapılan araştırmalarda, ögrrencilerin okuma düzeylerinin az olduğu ve bu nedenle de ögretim programlarında okumaya önem verilmesi gerektiği belirtilmektedir. $B u$ araştırma ilkokul 4. sinıf ögrencilerinin okuma motivasyonların etkileyen faktörlere iliş̧kin görüşlerini belirlemek amaciyla yapılmıştır. Araştırma Samsun Il MEM'e bağl devlet okullarında 2013-2014 eğitim-ögrretim yllında öğrenim gören 986 ilkokul 4. sinı öğrencisi üzerinde gerçekleştirilmişstir. Araştırmanın örneklemi oranlı küme örnekleme yöntemiyle belirlenmiş ve uygulama için gidilen okullar rastgele belirlenmiştir. Araştırmada ölçme aracı olarak 35 maddelik "İlkokul Öğrencilerinin Okumaya Güdüleyen Faktörlere İlişkin Görüşlerini Belirleme Anketi" kullanılmuştır. Verilerin analizlerinde frekans ve yüzde değerleri kullanılmıştır. Araştırmanın sonuçlarına göre, ögrencilerin okuma motivasyonlar ögretmenler ve kitaplar tarafindan daha sik etkilenmekte iken, aile ve arkadaşların daha az etkilediği belirlenmiştir. Ayrıca araştırmada kitap seçiminde en önemli unsurun kitabın konusu olduğu, tavsiye edilen kitapların ilgi alanlarına uygun olduğu, kitapların arkadaşlar arasinda değiştirilerek okunduğu ifade edilmiştir.
\end{abstract}

Reading is one of the basic skills that individuals use in their daily life. Reading is a complex process in which various functions of the eyes, sound and brain work together. In the researches, it is stated that the reading level of the students is low and therefore, reading should be given importance in curricula. This study was conducted to determine the opinions of 4th grade students studying in the primary school about the factors that affect their reading motivation. The research was carried out with 986 students of 4th graders in public schools of Samsun Provincial Directorate of National Education in 2013-2014 academic year. The sample of the study was determined by proportional cluster sampling method and schools were selected as randomized for application. As a measurement tool in the research, the 35-item "Questionnaire for Determining Primary School Students' Opinions on the Motivating Factors for Reading" was used. Frequency and percentage values were used in the analysis. According to the results of the research, determined that while the reading motivation of the students was more frequently affected by the teachers and the books, it was less affected by the family and friends. In addition, in the research, it was stated that the most important factor in choosing a book is the subject of the book, the recommended books that are suitable for their interests, and the boks that are read interchangeably among friends.

Karakullukçu, N., \& Çelik, Y. (2021). İlkokul dördüncü sınıf öğrencilerinin okuma motivasyonlarını etkileyen faktörlere ilişkin görüşleri. Muğla Sttkı Koçman Üniversitesi Eğitim Fakültesi Dergisi [MSKU Journal of Education], 8(2), 406-421, DOI: $10.21666 /$ muefd. 725816

\footnotetext{
${ }^{1}$ Ataköy İlyas Kılıç İlkokulu, İlkadım/SAMSUN, karakullukcu84@gmail.com, ORCID: 0000-0002-5019-3846

${ }^{2}$ Dr.Ögrr. Üyesi, Ondokuz Mayıs Üniv. Eğit. Fak., SAMSUN, ycelik@omu.edu.tr, ORCID: 0000-0001-8159-5189
} 
Bireyler sürekli öğrenme ve bilgilerini arttırma çabası içindedirler. Okuma bu amacın gerçekleşmesinde en önemli araçtır. Günlük hayatın her alanında sürekli yazılı materyallerle ve çeşitli bilgilerle karşı karşıya kalınmaktadır. Bu bilgilerin birçoğu okuma yoluyla kazanılmaktadır (Sünbül vd., 2010). Bireyin bilgi edinmek için kullandığı en kolay yollardan biri olan okuma, zihin gelişimine de önemli düzeyde katkı sağlamaktadır. Çünkü zihinsel kavramlara dönüştürülen yazılar, beyinde yapılandırılarak anlamlandırılmaktadır.

Türkçe dersi öğretim programında (Milli Eğitim Bakanlığı [MEB], 2005) okumaya farklı bir önem verilmektedir (Güneş, 2007). Programa göre okuma; göz, ses ve beynin (görme, algilama, seslendirme, anlama ve beyinde yapılandırma gibi) değişik işlevlerini kapsayan karmaşık bir süreç olarak görülmektedir (MEB, 2009). Öz (2011) okumayı gözün satırlar üzerinde sıçraması sonucu kelime şekillerini görerek, anlamlarını kavrama ve seslendirme olarak tanımlarken; kimi yazarlar ise okumayı, duyu organlarının yardımıyla sözcüklerin algılanıp anlam kazandırılmasına, kavranmasına ve yorumlanmasına dayanan zihinsel bir süreç olarak tanımlamışlardır (Sever, 2007; Özdemir, 2007; Harris \& Sipay, 1947). Okumaya dair yapılan tanımlar incelendiğinde okuma; görme, algılama, dikkat, hatırlama, anlamlandırma, yorumlama, sentez ve çözümleme gibi farklı zihinsel işlemlerin birlikte gerçekleştiği çok önemli bir eğitim aracı ve dil becerisi (Coşkun, 2006) olarak ifade edilebilir.

Okuma davranışının süreklilik kazanması için bireyin okumayı alışkanlık haline getirmesi gerekmektedir. Okuma alışkanlığı, bireyin merakı, ilgisi ve ihtiyaçları doğrultusunda, hoş vakit geçirme, eğlenme ve dinlenme maksatlarıyla zamanının bir kısmını okuyarak geçirmesi şeklinde tanımlanabilir (Yıldız, 2010). Ancak, üç yılda bir gerçekleştirilen PISA (Programme for International Student Assessment/ Uluslararası Öğrenci Değerlendirme Programı) sinavları ülkelerin eğitimdeki durumlarını sergilemesi bakımından önemlidir. $\mathrm{Bu}$ sınavlardaki okuma becerileri bakımından Türkiye'nin PISA sonuçları (2003, 2006, 2009, 2012, 2015 ve 2018) incelendiğinde ülkemiz listenin alt sıralarında yer almaktadır. PISA'nın okuma alanındaki değerlendirmelerine göre Türkiye 2003 yılında 41 ülke arasinda 34. sirada (MEB, 2005), PISA 2006' da 56 ülke arasinda 37. sirada (MEB, 2010a), PISA 2009'da 65 ülke arasında 39. sirada (MEB, 2010b), PISA 2012'de 65 ülke arasında 42. sirada (MEB, 2015), PISA 2015'te 72 ülke arasında 50. sirada yer alırken PISA 2018'de ise 79 ülke arasında 40. sırada (MEB, 2019a) bulunmaktadır. Elde edilen puanların, Ekonomik İşbirliği ve Kalkınma Örgütü (OECD) ülkelerinin ortalama okuma puanlarından düşük olması nedeniyle arzu edilen noktada olmadığını gözler önüne sermektedir. Bununla birlikte, öğrencilere okuma alışkanlığı kazandırmada bir model olarak önemli sorumluluklar yüklenen öğretmenlerin okuma alışkanlıklarına yönelik gerçekleştirilen araştırmalar (İskender, 2013; Karakullukçu \& Çelik, 2020; Tekgül, 2013; Tunç, 2018; Ülper, 2011b; Yalınkılıç, 2017) öğretmenlerin yeterli düzeyde okumadıklarını göstermektedir.

Eğitim sürecinde ve hayatın her aşamasında nasıl harekete geçirici bir mekanizmaya ihtiyaç varsa, okuma için de harekete geçirici bir mekanizmaya ihtiyaç vardır. Bu noktada karşımıza güdüleme (motivasyon) kavramı çıkmaktadır. Güdüleme; öğrenci davranışlarının yönünü, şiddetini, istikrarlı bir şekilde istenilen hedefe ulaştırmadaki hızı tespit eden asıl ve önemli güç unsurlarından birisidir. Güdülenmiş öğrenciler, herhangi bir uyarı ve yönlendirme olmaksızın firsat buldukça okumaya çalışırlar (Schunk, 2011). Okuduklarından ve öğrendiklerinden keyif alan, okudukları metinleri kavrayabilen, sentezleyebilen ve eleştirel bir bakış açısıyla değerlendirebilen bireyler yetiştirmek aynı zamanda Türkçe Öğretim Programı'nın özel amaçları arasında da yer almaktadır (MEB, 2019b).

Okuma açısından birçok güdü kaynağından söz edilse de asıl belirleyici olan içsel ve dişsal süreçlerdir. Kişinin bir çalışmaya katılması içsel güdüsüne ve çalışmaya yönelik olan bireysel ilgisine bağlı iken dişsal güdüsü ise dışsal değer ve ödüllere dayanmaktadır (Deci, Koestner \&Ryan, 2001). İçsel ve dışsal güdüler birlikte harekete geçirildiğinde okuma miktarının \%69'unu açıklayabilecek düzeye ulaşmaktadır (Schaffner vd. 2013). Bu bağlamda öğrencilerin hevesleri ve ilgileri doğrultusunda okumaları, içsel güdüyle bağlıdır. Ödüllendirilme, cezalandırılma, ebeveynlerle etkileşime girme, öğretmenlerin beklentilerini karşılama, çevresi tarafından iyi bir okur olarak görülme gibi nedenler ise dışsal güdüye bağlı okumalarını içermektedir. Ancak, dışsal güdüyle gerçekleştirilen davranışların belli bir zaman sonra içselleştirilip içsel güdü haline dönüştüğü de görülebilir (Hidi, 2000). Okunan metinden anlam çıkarma sürecinde takip edilen işlemler birçok motivasyonel süreci gerektirir (Monteiro, 2013). Okumaya güdülemede dört temel unsurun öne çıktığı gözükmektedir. Bunlar öğretmen, aile, arkadaş ve kitaptır. Çocuk, okuduklarını çevresiyle (ebeveyn, arkadaşları vb.) paylaşmak, arkadaşları ile yarışmak ya da öğretmeni tarafından ödüllendirilmek için okumaya vakit 
ayırabilir. Aile fertleri okumaya değer veriyorsa, çocukları da okuma becerilerini arttırmak için okumaya ilgi duyabilir (Y1ld1z \& Akyol, 2011).

Okuma alı̧skanlığı kazanmada okuma motivasyonunun önemi, etkisi, okuma motivasyonu ile okuduğunu anlama arasındaki ilişkiyi inceleyen birçok araştırmaya (Aktaş \& Çankal, 2019; Arıcı, 2005; Baki, 2019; Batmaz \&Erdoğan, 2019; Boerma, Mol \& Jolles, 2016; Guthrie vd.,1993; Kızgın \& Batuğ, 2020; Kuşdemir \& Güneş, 2015; Özerbaş \& Öztürk, 2017; Sanc1, 2002; Wigfield, Gladstone \& Turci, 2016) rastlanmaktadır. İlkokul düzeyinde ve okuma motivasyonlarını etkileyen faktörleri konu alan araştırmalar (Aksoy ve Öztürk, 2018; Aslan ve Harput, 2017; Bamberger, 1990; Duran \& Sezgin, 2012; Gök, 2019; Gökçe, 2012; Katranc1, M. 2015; Öztürk \& Aydemir, 2012; Suna, 2006: Tunç, 2018; Ülper, 2011a; Yamaç \& Çeliktürk Sezgin, 2018; Yıldız \& Akyol, 2011) oldukça sınırlıdır. Okuma motivasyonu bazı araştırmalarda değişik yönlerden ele alınarak incelenmekle birlikte; doğrudan öğretmen, aile, kitap ve arkadaş boyutlarıyla ele alarak inceleyen araştırmaya az rastlandığı görülmüştür. Okuma konusundaki temellerin büyük oranda ilkokul düzeyinde atıldığı ve okuma alışkanlığı kazanmada bireylerin okuma motivasyonlarının önemli bir etkisi olduğu bilinen bir gerçektir. Bu nedenle ilkokul düzeyindeki öğrencilerin okuma motivasyonunu etkileyen faktörleri tespit etmek ve bu konuda bazı önerilerde bulunmak amacıyla geniş bir katılımcı grubu üzerinde yapılan bu araştırmanın alana katkı sağlayacağı umulmaktadır.

\section{Araştırmanın Amacı}

$\mathrm{Bu}$ araştırmanın amacı, İlkokul 4. sınıf öğrencilerinin okuma motivasyonlarını etkileyen faktörlere ilişkin görüşlerinin bazı değişkenlere göre incelenmesidir. Bu bağlamda aşağıdaki sorulara yanıt aranmıştır:

1. İlkokul 4. sınıf öğrencilerinin okuma motivasyonlarını etkileyen faktörlerden öğretmen boyutu ile ilgili görüşleri nelerdir?

2. İlkokul 4. sınıf öğrencilerinin okuma motivasyonlarını etkileyen faktörlerden aile boyutu ile ilgili görüşleri nelerdir?

3. İlkokul 4. sınıf öğrencilerinin okuma motivasyonlarını etkileyen faktörlerden arkadaş boyutu ile ilgili görüşleri nelerdir?

4. İlkokul 4. sınıf öğrencilerinin okuma motivasyonlarını etkileyen faktörlerden kitap boyutu ile ilgili görüşleri nelerdir?

\section{Yöntem}

$\mathrm{Bu}$ araştırma yüksek lisans tezinden üretilmiş olup, öğrencinin belirlenen sürede mezun olamayıp ilişiğinin kesilmesinden dolayı çalışmaya bir süre ara verilmiştir. Öğrencinin "öğrenci affindan" geri dönmesi ile birlikte çalışmaya kalınan noktadan devam edilmiştir. Bu yüzden araştırmada 2013-2014 yılına ait veriler kullanılmıştır.

\section{Araştırmanın Modeli}

$\mathrm{Bu}$ araştırmada betimsel araştırma yöntemlerinden tarama modeli kullanılmıştır. Tarama modelleri; bir grubu oluşturan bireylerin çeşitli özelliklerini ortaya koymak amaciyla verilerin toplanmasını gerektirmektedir (Büyüköztürk vd., 2008). Bu nedenle tarama modelleri, mevcut duruma müdahale etmeden, içinde bulunulan koşullar dahilinde betimleme imkanı sağlamaktadır (Karasar, 2012).

\section{Evren ve Örneklem}

Araştırmanın evrenini, 2013-2014 eğitim-öğretim yılında Milli Eğitim Bakanlığı'na bağlı Samsun'daki ilkokullarda öğrenim gören 4. sınıf öğrencileri oluşturmaktadır. Araştırmada evreninin büyük olması nedeniyle örnekleme yöntemlerinden oranlı küme örnekleme yoluyla örneklem alınmıştır. Küme örneklemede, evren ya da alt evrendeki tüm elemanlar kümeler halindedir. Örnekleme, bu kümeler arasında yapılmaktadır. Oranlı küme örnekleme ise, her bir alt evrenden, o alt evrenin bütün içindeki oranına uygun şekilde küme belirlenir (Karasar, 2012).

Araştırmada, okullar yerleşim yerlerine göre "1. eğitim bölgesi" ve "2. eğitim bölgesi" olacak şekilde Samsun ili iki eğitim bölgesine gruplandırılarak alt evrenini oluşturmuştur. Bu gruplama Millî Eğitim Bakanlığı Öğretmen Atama ve Yer Değiştirme Yönetmeliğine göre belirlenen hizmet bölgesi ve 
hizmet alanlarına göre yapılmıştır (MEB, 2018). Yönetmeliğe göre Samsun ili hizmet bölgesi olarak 1. hizmet bölgesinde yer almaktadır ve okulun bulduğu yerleşim yerinin durumuna göre Samsun İli 6 alt hizmet alanına ayrılmıştır. Araştırmada, hizmet alanı 1, 2 ve 3 olan okullar 1. eğitim bölgesi; hizmet alanı 4, 5 ve 6 olan okullar ise 2. eğitim bölgesi olarak kabul edilmiştir.

Araştırmanın gerçekleştirildiği 2013-2014 eğitim-öğretim yılında Samsun İl Milli Eğitim Müdürlüğü'ne bağlı okullarda ilkokula devam eden 4. sınıf öğrencilerinin sayıs1 17933'tür. Örneklemin evreni temsil yeterliliği ile ilgili, \%95 kesinlik düzeyi ve tolerans gösterilebilir hata oranına göre 20000 kişilik bir evren için 644 kişi yeterli örneklemi oluşturmaktadır (Büyüköztürk \& vd. 2008). Örneklemin çeşitli yönlerden dağılımını görmek amacıyla öğrencilerin cinsiyet, eğitim bölgesi, kardeş sayısı, anne öğrenim durumu ve baba öğrenim durumlarına göre dağılımları Tablo 1 'de verilmiştir.

Tablo 1

Örneklemi Oluşturan Öğrencilerin Kişisel Özellikleri

\begin{tabular}{llcc}
\hline Değişkenler & & Frekans (f) & Yüzde (\%) \\
\hline \multirow{2}{*}{ Cinsiyet } & Kız & 503 & 51,01 \\
Eğitim Bölgesi & Erkek & 483 & 48,99 \\
\cline { 2 - 4 } & 1. Eğitim Bölgesi & 588 & 59,63 \\
& 2. Eğitim Bölgesi & 398 & 40,37 \\
\cline { 2 - 4 } Kardeş Sayısı & 0 & 86 & 8,72 \\
& 1 & 286 & 29,01 \\
& 2 & 261 & 26,47 \\
& 3 ve daha fazla & 353 & 35,80 \\
\cline { 2 - 4 } Anne Öğrenim Durumu & Okuryazar Değil & 106 & 10,75 \\
& İlkokul & 463 & 46,96 \\
& Ortaokul & 189 & 19,17 \\
& Lise & 130 & 13,18 \\
& Üniversite & 98 & 9,94 \\
\cline { 2 - 4 } Baba Öğrenim Durumu & İlkokul & 413 & 41,9 \\
& Ortaokul & 231 & 23,43 \\
& Lise & 169 & 17,14 \\
& Üniversite & 173 & 17,54 \\
\hline
\end{tabular}

Tablo 1'e göre araştırmaya katılan öğrencilerin cinsiyete göre dağılımları incelendiğinde öğrencilerin $\% 51,01$ 'inin ( $\mathrm{f}=503) \mathrm{kız}, \% 48,99$ 'unun ise $(\mathrm{f}=483)$ erkek olduğu görülmektedir. Cinsiyet bakımından araştırma örneklemine alınan 986 öğrenci sayısı birbirine denktir. Uygulama esnasında kız ve erkek öğrenci sayısını eşitlemeye gidilmemiştir; ancak cinsiyet açısından öğrencilerin eşit sayıda olduğu söylenebilir. Kız ve erkek öğrencilerin dengeli bir dağılımda olması sonuçların cinsiyete göre genellenebilmesi açısından da önemlidir.

Araştırmaya katılan öğrencilerin eğitim bölgelerine göre dağılımları incelendiğinde, \%59,63'ünün $(\mathrm{f}=588)$ 1. eğitim bölgesinde, \%40,37'sinin $(\mathrm{f}=398)$ 2. eğitim bölgesinde bulunan okullardan araştırmaya katılmış oldukları görülmektedir. Araştırma öncesinde öğrenci sayıları bölgeler arası dengede tutulsa da anket analizinde eksik ve hatalı anketler değerlendirme dışı bırakılması nedeniyle sayısal farklar oluşmuştur. 2. eğitim bölgesinde bulunan okullardan gelen anketlerde hatalı anket sayısının 1. eğitim bölgesinde göre yüksek olduğu görülmektedir.

Araştırmaya katılan öğrencilerin kardeş sayısına göre dağılımları incelendiğinde öğrencilerin \%8,72'sinin ( $\mathrm{f}=86$ ) hiç kardeşinin bulunmadığı, \%29,01'inin ise ( $\mathrm{f}=286)$ "1" kardeşinin bulunduğu, $\% 26,47$ 'sinin ( $\mathrm{f}=261$ ) "2" kardeşinin olduğunu ve \%35,80'inin ( $\mathrm{f}=353)$ " 3 ve daha fazla" kardeşinin olduğunu görülmektedir. 
Araştırmaya katılan öğrencilerin annelerinin öğrenim durumlarına göre dağılımları incelendiğinde; annelerin \%10,75'inin ( $\mathrm{f}=106$ ) okuryazar olmadığ 1 , \%46,96'sının ( $\mathrm{f}=463$ ) ilkokul mezunu olduğu, $\% 19,17$ 'sinin ( $\mathrm{f}=192)$ ortaokul mezunu olduğunu, \%13,18'inin ( $\mathrm{f}=130$ ) lise mezunu olduğunu ve $\% 9,94$ 'ünün $(\mathrm{f}=98)$ üniversite mezunu olduğunu görülmektedir. Araştırmaya katılan öğrencilerin babalarının öğrenim durumlarına göre dağılımları incelendiğinde; babaların \%41,9'unun (f=413) ilkokul mezunu olduğu, \%23,43'ünün ( $\mathrm{f}=231)$ ortaokul mezunu olduğunu, \%17,14'ünün ( $\mathrm{f}=169)$ lise mezunu olduğu ve \%17,54'ünün ( $\mathrm{f}=173$ ) üniversite mezunu olduğu görülmektedir. Genel anlamda anne ve babaların ilkokul mezunu oldukları görülmektedir; ancak babaların annelere oranla öğrenim düzeylerinin daha yüksek olduğunu söylemek mümkündür.

\section{Veri Toplama Araci}

İlkokul 4. sınıf öğrencilerinin okuma motivasyonlarını etkileyen faktörlere ilişkin görüşlerini belirlenmesi amacıyla yapılan alanyazın taraması sonucunda, araştırmanın amacina uygun olduğu düşünülen ve Ülper (2011a) tarafindan geliştirilen, 35 maddelik "İlkokul öğrencilerinin okumaya güdüleyen faktörlere ilişkin görüşlerini belirleme anketi” kullanılmıştır. Ülper (2011a) tarafından alan yazından okumaya güdüleyici etmenler belirlenerek oluşturulan bilgi tabanına dayanarak; öğretmen boyutu, aile boyutu, arkadaş boyutu ve kitap boyutu olmak üzere dört boyut belirlenmiştir. $\mathrm{Bu}$ boyutlarla ilgili toplam 41 maddelik bir soru havuzu oluşturmuş ve bu sorulara ilişkin uzman kişilerin görüş ve önerileri aldıktan sonra 6 madde çıkarılmıştır. Geriye kalan maddeleri öğrenci düzeyine uygunluğu bakımından ilkokul, ortaokul ve lise öğretmenlerince dil ve anlatım özellikleri bakımından değerlendirmiştir. Anketin beşli likert türünde hazırlanmış olup, verilen yanıtlar "hiçbir zaman karşılaşmam", "ender olarak karşılaşırım", "ara sıra karşılaşırım", "sık sık karşılaşırım" ve "her zaman karşılaşırım" şeklindedir. Araştırmada ön uygulama, örneklem haricinde benzer türdeki okullardan seçkisiz olarak belirlenen 150 öğrenci ile gerçekleştirilmiştir. Gerçekleştirilen bu uygulamaya göre anketin Cronbach' Alfa güvenirlik katsayısı ,92 olarak tespit edilmiştir. Güvenirlik katsayısı, kuramsal tanımı gereği puanlarda hata olmaması durumunda 1, gözlenen puanların tümü hatalı olması durumunda 0 olur (Büyüköztürk vd., 2008). Tüm bu işlemler sonucunda ölçeğin geçerli ve güvenilir olduğu kanaatine ulaşılmıştır. Anket iki bölümden, toplam 40 sorudan oluşmaktadır. Anketin birinci bölümünde öğretmenlerin kişisel özelliklerine ilişkin verilere ulaşmak amacıyla 5 sorudan oluşan kişisel bilgiler formu yer almaktadır. Anketin ikinci bölümünde ise Ülper (2011a) tarafından geliştirilen, 5 likert tipinde ölçeklendirilmiş, 35 sorudan oluşan ilkokul öğrencilerinin okumaya güdüleyen faktörlere ilişkin görüşlerini belirleme anketi yer almaktadır.

\section{Verilerin Toplanması}

Araştırmacı tarafından ölçek sahibinden, e-posta yoluyla gerekli izin alınmış, uygulama için hazır duruma getirilerek çoğaltılmıştır. Diğer taraftan örnekleme seçilen okullarda anketlerin uygulanabilmesi için Samsun İl Milli Eğitim Müdürlügü̈ne başvurularak gerekli onay alınarak uygulamaya başlanmıştır. Uygulama için gidilen okullar rastgele (random) seçilmiştir. Anketler araştırmacı veya öğretmenler tarafından 4. sınıf öğrencilerine uygulanmıştır. Veri toplama aracının ögrenciler tarafindan doldurulması yaklaşık 30'ar dakika sürmüştür. Sonuçta, anketler örneklemde belirtilen okullarda uygulanarak araştırma için gerekli veriler toplanmıştır.

\section{Verilerin Analizi}

Verilerin çözümlenmesi öncesinde, 1160 öğrenciden toplanan anketlerden hatalı veya eksik doldurulan toplam 174 anket değerlendirme dışı bırakılmış, uygun olan 986 anket analize tabi tutulmuştur. "İlkokul öğrencilerinin okumaya güdüleyen faktörlere ilişkin görüşlerini belirleme anketi”ne ait verilerin bilgisayar ortamına girilmesinde, düzenlenmiş maddelerin her biri için "hiçbir zaman karşılaşmam" seçeneği 1, "ender olarak karşılaşırım” seçeneği 2, "ara sıra karşılaşırım” seçeneği 3, "sık sık karşılaşırım" seçeneği 4 ve "her zaman karşılaşırım" seçeneği 5 şeklinde kodlanarak veri girişi sağlanmıştır. Araştırmada elde edilen verilerin analizinde SPSS24 veri analiz programı kullanılmıştır. Ülper (2011a) tarafindan geliştirilip araştırmada veri toplama aracı olarak kullanılan ankette yer alan maddeler, bu araştırmada da Ülper'in (2011a) kendi çalışmasında yapmış olduğu gibi dört boyutta boyutlandırılmıştır. Boyutlara ait maddeler Tablo 2'de yer verilmiştir. 
Tablo 2

Boyutlara Ait Madde Numaraları

\begin{tabular}{ll}
\hline Boyutlar & Maddeler \\
\hline Öğretmen Boyutu & $1,2,3,4,5,6,7,8,9,10$ \\
Aile Boyutu & $11,12,13,14,15,16,17,18,19,20$ \\
Arkadaş Boyutu & $21,22,23,24,25,26,27,28,29,30$ \\
Kitap Boyutu & $31,32,33,34,35$ \\
\hline
\end{tabular}

Araştırmada katılımcıların anket maddelerine verdikleri yanıtlar SPSS 24 veri analiz programı ile analiz edilerek, elde edilen bulgular yüzde ve frekans dağılımları şeklinde sunulmuştur.

\section{Bulgular}

Araştırmanın bu bölümünde, araştırmanın amacı doğrultusunda verilerin analizi sonucunda elde edilen bulgulara yer verilmiştir.

\section{İlkokul 4. Sınıf Öğrencilerinin Okuma Motivasyonlarını Etkileyen Faktörlerden Öğretmen Boyutu ile İlgili Görüşleri}

Tablo 3

Öğrencilerin Okuma Motivasyonların Etkileyen Faktörlerden Öğretmen Boyutu İle İlgili Görüşlerinin Dağılımı

\begin{tabular}{|c|c|c|c|c|c|c|c|c|c|c|}
\hline \multirow{2}{*}{ Maddeler } & \multicolumn{2}{|c|}{ Hiçbir zaman } & \multicolumn{2}{|c|}{ Ender } & \multicolumn{2}{|c|}{ Ara sira } & \multicolumn{2}{|c|}{ Sık sık } & \multicolumn{2}{|c|}{ Her zaman } \\
\hline & f & $\%$ & f & $\%$ & f & $\%$ & f & $\%$ & $\mathbf{f}$ & $\%$ \\
\hline $\begin{array}{l}\text { 1. Öğretmenlerimi kitap } \\
\text { okurken görürüm. }\end{array}$ & 58 & 5,88 & 79 & 8,01 & 383 & 38,85 & 220 & 22,31 & 246 & 24,95 \\
\hline $\begin{array}{l}\text { 2. Öğretmenlerimiz } \\
\text { okudukları kitapları önerir. }\end{array}$ & 121 & 12,27 & 108 & 10,95 & 221 & 22,42 & 218 & 22,11 & 318 & 32,25 \\
\hline $\begin{array}{l}\text { 3. Öğretmenlerimiz } \\
\text { okuduklarını anlatır. }\end{array}$ & 181 & 18,36 & 121 & 12,27 & 264 & 26,77 & 173 & 17,55 & 247 & 25,05 \\
\hline $\begin{array}{l}\text { 4. Öğretmenlerimiz } \\
\text { okudukları kitapları tanıtır. }\end{array}$ & 163 & 16,53 & 144 & 14,60 & 250 & 25,36 & 182 & 18,46 & 247 & 25,05 \\
\hline $\begin{array}{l}\text { 5. Öğretmenlerimiz okuyup } \\
\text { okumadığımızı takip eder }\end{array}$ & 42 & 4,26 & 37 & 3,75 & 143 & 14,51 & 164 & 16,63 & 600 & 60,85 \\
\hline $\begin{array}{l}\text { 6. Öğretmenlerimiz } \\
\text { derslerde değişik okuma } \\
\text { metinleri kullanır. }\end{array}$ & 62 & 6,29 & 100 & 10,14 & 221 & 22,41 & 231 & 23,43 & 372 & 37,73 \\
\hline $\begin{array}{l}\text { 7. Öğretmenlerimiz } \\
\text { derslerde çeşitli okuma } \\
\text { etkinlikleri yaptırır. }\end{array}$ & 44 & 4,46 & 66 & 6,69 & 218 & 22,11 & 244 & 24,75 & 414 & 41,99 \\
\hline $\begin{array}{l}\text { 8.Öğretmenlerimiz bizi kitap } \\
\text { okumak için teşvik eder. }\end{array}$ & 37 & 3,75 & 43 & 4,36 & 127 & 12,88 & 183 & 18,56 & 596 & 60,45 \\
\hline $\begin{array}{l}\text { 9. Öğretmenlerimiz kitap } \\
\text { hediye eder. }\end{array}$ & 140 & 14,20 & 106 & 10,75 & 291 & 29,51 & 202 & 20,49 & 247 & 25,05 \\
\hline $\begin{array}{l}\text { 10. Ögrretmenlerimiz kitap } \\
\text { okuyanlar1 över. }\end{array}$ & 67 & 6,80 & 85 & 8,62 & 199 & 20,18 & 181 & 18,36 & 454 & 46,04 \\
\hline
\end{tabular}

Tablo 3 incelendiğinde öğrencilerin, öğretmenlerini kitap okurken "ara sıra" gördükleri $(\% 38,85)$, öğretmenlerin okuduklarını "ara sıra" anlattıkları (\%26,77), okudukları kitapları "ara sıra" tanıttıkları $(\% 25,36)$, "ara sıra" kitap armağan ettikleri $(\% 29,51)$; öğretmenlerin, okudukları kitapları "her zaman" önerdikleri $(\% 32,25$, kitap okuyup okumadıklarını "her zaman izledikleri" $(\% 60,85)$, farklı okuma metinlerini "her zaman" kullandıkları $(\% 37,73)$, derslerde "her zaman" çeşitli okuma etkinlikleri yaptırdıkları $(\% 41,99)$, kitap okumaya "her zaman" teşvik ettikleri $(\% 60,45)$ ve kitap okuyanları "her 
zaman" övdükleri $(\% 46,04)$ anlaşılmaktadır. Bunlardan öğretmenlerimiz kitap okuyup okumadığımızı "her zaman" izler $(\% 60,85)$ ve kitap okumaya "her zaman" teşvik eder $(\% 60,45)$ ifadeleri, ögretmenlerin öğrencilerin okuma alışkanlığı kazanma konusunda gereken özeni gösterdikleri şeklinde yorumlanabilir.

\section{İlkokul 4. Sınıf Öğrencilerinin Okuma Motivasyonlarını Etkileyen Faktörlerden Aile Boyutu ile İlgili Görüşleri}

Tablo 4

Ögrrencilerin Okuma Motivasyonlarını Etkileyen Faktörlerden Aile Boyutu İle İlgili Görüşlerinin Dağllımı

\begin{tabular}{lcccccccccc}
\hline Maddeler & $\begin{array}{c}\text { Hiçbir } \\
\text { zaman } \\
\text { f }\end{array}$ & \multicolumn{2}{c}{ Ender } & \multicolumn{2}{c}{ Ara sıra } & \multicolumn{2}{c}{ Sık stk } & \multicolumn{3}{c}{ Her zaman } \\
\hline $\begin{array}{l}\text { 11. Ailem yeni çıkan okuma } \\
\text { materyallerini satın alır. }\end{array}$ & 203 & 20,59 & 156 & 15,82 & 303 & 30,73 & 151 & 15,31 & 173 & 17,55 \\
\hline $\begin{array}{l}\text { 12. Evimizde kitap okuma } \\
\text { saatleri belirlenir. }\end{array}$ & 233 & 23,63 & 129 & 13,08 & 209 & 21,20 & 160 & 16,23 & 255 & 25,86 \\
\hline $\begin{array}{l}\text { 13. Ailemi kitap okurken } \\
\text { görürüm. }\end{array}$ & 224 & 22,72 & 167 & 16,94 & 254 & 25,76 & 150 & 15,21 & 191 & 19,37 \\
$\begin{array}{l}\text { 14. Ailem okuduğu } \\
\text { kitapları önerir. }\end{array}$ & 224 & 22,72 & 145 & 14,71 & 193 & 19,57 & 158 & 16,02 & 266 & 26,98 \\
\hline $\begin{array}{l}\text { 15. Ailem okuduklarını } \\
\text { bana anlatır. }\end{array}$ & 293 & 29,72 & 136 & 13,79 & 215 & 21,81 & 143 & 14,50 & 199 & 20,18 \\
\hline $\begin{array}{l}\text { 16. Ailem okuduklarım1 } \\
\text { anlatmamı ister. }\end{array}$ & 80 & 8,11 & 104 & 10,55 & 195 & 19,78 & 199 & 20,18 & 408 & 41,38 \\
\hline $\begin{array}{l}\text { 17.Ailem okuduğu } \\
\text { kitapları bana tanıtır. }\end{array}$ & 235 & 23,83 & 134 & 13,59 & 216 & 21,91 & 146 & 14,81 & 255 & 25,86 \\
\hline $\begin{array}{l}\text { 18. Ailem beni kitap } \\
\text { okumaya teşvik eder. }\end{array}$ & 54 & 5,48 & 32 & 3,25 & 149 & 15,11 & 205 & 20,79 & 546 & 55,37 \\
\hline $\begin{array}{l}\text { 19. Ailem bana kitap } \\
\text { hediye eder. }\end{array}$ & 127 & 12,88 & 107 & 10,85 & 324 & 32,86 & 168 & 17,04 & 260 & 26,37 \\
\hline $\begin{array}{l}\text { 20. Ailem kitap okuduğum } \\
\text { için beni över. }\end{array}$ & 79 & 8,01 & 77 & 7,81 & 184 & 18,66 & 208 & 21,10 & 438 & 44,42 \\
\hline
\end{tabular}

Tablo 4 incelendiğinde öğrenciler ailelerinin, "hiçbir zaman" okuduklarını kendilerine anlatmadığı $(\% 29,72)$; yeni çıkmış çeşitli okuma materyallerini "ara sıra" satın aldıkları (\%30,73); ailelerini kitap okurken "ara sıra" gördükleri $(\% 25,76)$, ailelerinin kendilerine "ara sıra" kitap armağan ettikleri $(\% 32,86)$; evde "her zaman kitap okuma saatleri belirlendiği $(\% 25,86)$, ailelerinin okudukları kitapları "her zaman" önerdikleri (\%26,98), "her zaman" okuduklarını kendilerine anlatılmasını istedikleri (\% 41,38), okudukları kitapları "her zaman" kendilerine tanıttıkları $(\% 25,86)$, "her zaman" kendilerini kitap okumaya teşvik ettikleri $(\% 55,37)$ ve kitap okudukları için "her zaman" kendilerini övdükleri $(\% 44,42)$ anlaşılmaktadır. Öğrencilerin ailelerinin kendilerini "her zaman" kitap okumaya teşvik ettikleri $(\% 55,37)$ ve kitap okudukları için "her zaman" kendilerini övdükleri $(\% 44,42)$ yönündeki ifadeler ailelerin çocukları teşvik etme konusunda olumlu davranış sergiledikleri şeklinde yorumlanabilir.

\section{İlkokul 4. Sınıf Öğrencilerinin Okuma Motivasyonlarını Etkileyen Faktörlerden Arkadaş Boyutu ile İlgili Görüşleri}

Tablo 5 incelendiğinde öğrenciler arkadaşlarının, kendilerine "hiçbir zaman" okuduklarını anlattırmak istemedikleri $(\% 27,99)$, "hiçbir zaman" kitap armağan etmedikleri $(\% 36,81)$, kitap okudukları için arkadaşlarının "hiçbir zaman" kendilerini övmedikleri $(\% 35,60)$, yeni çıkmış okuma materyalleri ile "ara sıra" ilgilendikleri $(\% 28,40)$, okudukları kitapları "ara sıra" önerdikleri $(\% 28,19)$, okuduklarını

"ara sıra" anlattıkları (\%26,57), okudukları kitapları "ara sıra" tanıttıkları $(\% 23,43)$; kendilerini "ara sıra" okumaya teşvik ettikleri $(\% 24,14)$, okudukları kitapları arkadaşları ile "her zaman" değiştikleri 
$(\% 39,15)$ ve arkadaşlarını "her zaman" kitap okurken gördükleri $(\% 41,18)$ anlaşılmaktadır. Bunlardan arkadaşlarının kitap okuduğu için kendilerini "hiçbir zaman" övmedikleri (\%35,60), okudukları kitapları "her zaman" değiştikleri $(\% 39,15)$, arkadaşlarını kitap okurken "her zaman" gördükleri $(\% 41,18)$ şeklindeki sonuçlar öğrencilerin birbirlerini okumaya teşvik etmedikleri, birbirleriyle yeterli düzeyde kitap değişiminde bulunmadıkları ve kitap okuma alışkanlıklarının yeterli düzeyde olmadığı şeklinde yorumlanabilir.

Tablo 5

Öğrencilerin Okuma Motivasyonların Etkileyen Faktörlerden Arkadaş Boyutu İle İlgili Görüşlerinin Dağllımı

\begin{tabular}{lcccccccccc}
\hline \multirow{2}{*}{ Maddeler } & \multicolumn{2}{c}{ Hiçbir } & \multicolumn{2}{c}{ Ender } & \multicolumn{2}{c}{ Ara sıra } & \multicolumn{2}{c}{ Sik sık } & \multicolumn{2}{c}{ Her } \\
& famanan \\
& f & $\mathbf{\%}$ & f & \% & f & \% & f & \% & f & \% \\
\hline $\begin{array}{l}\text { 21. Arkadaşlarımla } \\
\text { okuduğumuz kitapları değişiriz. }\end{array}$ & 78 & 7,91 & 76 & 7,71 & 233 & 23,63 & 213 & 21,60 & 386 & 39,15 \\
\hline
\end{tabular}

22. Arkadaşlarım yeni çıkan $\begin{array}{lllllllllll}\text { okuma materyalleriyle ilgilenir. } & 173 & 17,55 & 129 & 13,08 & 280 & 28,40 & 217 & 22,01 & 187 & 18,96\end{array}$

\begin{tabular}{lcccccccccc}
\hline $\begin{array}{l}\text { 23. Arkadaşlarımı kitap } \\
\text { okurken görürüm. }\end{array}$ & 46 & 4,66 & 51 & 5,17 & 232 & 23,53 & 251 & 25,46 & 406 & 41,18 \\
\hline $\begin{array}{l}\text { 24. Arkadaşlarım bana } \\
\text { okudukları kitapları önerir. }\end{array}$ & 124 & 12,58 & 116 & 11,76 & 278 & 28,19 & 208 & 21,10 & 260 & 26,37 \\
\hline $\begin{array}{l}\text { 25. Arkadaşlarım } \\
\text { okuduklarıı bana anlatır. }\end{array}$ & 204 & 20,69 & 173 & 17,55 & 262 & 26,57 & 179 & 18,15 & 168 & 17,04 \\
\hline $\begin{array}{l}\text { 26. Arkadaşlarım okuduklarımı } \\
\text { anlatmamı ister. }\end{array}$ & 276 & 27,99 & 156 & 15,82 & 226 & 22,92 & 155 & 15,72 & 173 & 17,55 \\
\hline $\begin{array}{l}\text { 27. Arkadaşlarım okudukları } \\
\text { kitapları bana tanıtır. }\end{array}$ & 159 & 16,12 & 188 & 19,07 & 231 & 23,43 & 202 & 20,49 & 206 & 20,89 \\
\hline $\begin{array}{l}\text { 28. Arkadaşlarım beni kitap } \\
\text { okumaya teşvik eder. }\end{array}$ & 215 & 21,8 & 146 & 14,81 & 238 & 24,14 & 171 & 17,34 & 216 & 21,91 \\
\hline $\begin{array}{l}\text { 29. Arkadaşlarım bana kitap } \\
\text { hediye eder. }\end{array}$ & 363 & 36,81 & 183 & 18,56 & 216 & 21,91 & 117 & 11,87 & 107 & 10,85 \\
\hline $\begin{array}{l}\text { 30. Arkadaşlarım kitap } \\
\text { okuduğum için beni över }\end{array}$ & 351 & 35,60 & 154 & 15,62 & 185 & 18,76 & 140 & 14,20 & 156 & 15,82 \\
\hline
\end{tabular}

\section{İlkokul 4. Sınıf Öğrencilerinin Okuma Motivasyonlarını Etkileyen Faktörlerden Kitap Boyutu ile İlgili Görüsşleri}

Tablo 6 incelendiğinde öğrenciler, okumaları tavsiye edilen kitapları, "her zaman" ilgi alanlarına uygun buldukları $(\% 42,90)$, "her zaman" düzeylerine uygun buldukları $(\% 46,75)$, "her zaman" yararlı buldukları (\%51,32), "her zaman" özgürce seçtikleri (\%57) ve "her zaman" eğlenceli buldukları $(\% 56,39)$ anlaşılmaktadır. Bu bulgulardan yola çıkarak öğrencilerin kitap okumaya yönelik motivasyonlarının orta seviyede olduğu söylenebilir. 
Tablo 6

Öğrencilerin Okuma Motivasyonlarını Etkileyen Faktörlerden Kitap Boyutu İle İlgili Görüşlerinin Dağılımı

\begin{tabular}{lccccccccccc}
\hline Maddeler & \multicolumn{2}{c}{$\begin{array}{c}\text { Hiçbir } \\
\text { zaman }\end{array}$} & \multicolumn{2}{c}{ Ender } & \multicolumn{2}{c}{ Ara sıra } & \multicolumn{2}{c}{ Sık sık } & \multicolumn{2}{c}{ Her zaman } \\
& $\mathbf{f}$ & $\mathbf{\%}$ & $\mathbf{f}$ & $\mathbf{\%}$ & $\mathbf{f}$ & $\mathbf{\%}$ & $\mathbf{f}$ & $\mathbf{\%}$ & $\mathbf{f}$ & $\mathbf{\%}$ \\
\hline $\begin{array}{l}\text { 31. Okumam istenen } \\
\text { kitapları ilgi alanıma uygun } \\
\text { bulurum. }\end{array}$ & 50 & 5,07 & 99 & 10,04 & 207 & 20,99 & 207 & 20,99 & 423 & 42,90 \\
$\begin{array}{l}\text { 32. Okumam istenen } \\
\text { kitapları seviyeme uygun } \\
\text { bulurum. }\end{array}$ & 35 & 3,55 & 77 & 7,81 & 180 & 18,26 & 233 & 23,63 & 461 & 46,75 \\
$\begin{array}{l}\text { 33. Okumam istenen } \\
\text { kitapları faydalı bulurum. }\end{array}$ & 39 & 3,96 & 63 & 6,39 & 156 & 15,82 & 222 & 22,51 & 506 & 51,32 \\
\hline $\begin{array}{l}\text { 34. Okumam gereken } \\
\text { kitaplar kendi seçtĭgim } \\
\text { kitaplardır. }\end{array}$ & 30 & 3,04 & 53 & 5,38 & 134 & 13,59 & 207 & 20,99 & 562 & 57,00 \\
\hline $\begin{array}{l}\text { 35.Okumam istenen } \\
\text { kitapları eğlenceli bulurum. }\end{array}$ & 27 & 2,74 & 48 & 4,87 & 161 & 16,33 & 194 & 19,67 & 556 & 56,39 \\
\hline
\end{tabular}

\section{Sonuç ve Tartışma}

$\mathrm{Bu}$ araştırmada öğrenciler ağırlıklı olarak öğretmenlerini, kitap okurken "ara sıra" gördüklerini $(\% 38,85)$, öğretmenlerin, okudukları kitapları "her zaman" önerdiklerini $(\% 32,25$, öğrencilerin kitap okuyup okumadıklarını "her zaman izlediklerini" $(\% 60,85)$ ve kitap okuyanları "her zaman" övdüklerini $(\% 46,04)$ belirtmişlerdir. $\mathrm{Bu}$ verilerden hareketle öğretmenlerin yeterince model olmadıkları ancak öğrencileri okumaya teşvik ettikleri söylenebilir. Literatürde yer alan araştırmalara (Akyol \& Çoban Sural 2021; Duran \& Sezgin, 2012; Karakullukcu \& Çelik, 2020; Karatay, Külah \& Kaya, 2020; Kızgın \& Baştuğ, 2020; Tekgül, 2013; Ülper, 2011a; Ülper, 2011b; Yalınkılıç, 2017; Yılmaz \& Ertem, 2020) bakıldığında bu araştırmanın sonuçlarını destekler nitelikte olduğu söylenebilir.

Temel eğitim aşamasında öncelikle öğretmenlerin okuma konusunda olumlu tutuma sahip olması ve bu konuda gerekli adımları atmış olması beklenmektedir. Çünkü öğretmen, çocuğun ilköğretime adım atmasıyla birlikte ebeveyninden sonra model aldığı kişidir. Bu nedenle öğretmenin kişiliği, okumaya karşı olan olumlu tutumu, çocukta okuma ilgisi geliştirmede ve çocuklara olumlu bir rol model olması konusunda son derece önemlidir (Bamberger, 1990;Tunç, 2018). Yalınkılıç (2017) çalışmasında öğretmenlerin, öğrencilerin okuma motivasyonlarını artırmak için daha duyarlı davranmalarını, gerek örnek olmak, gerekse okuma derslerinin iyi ve güçlü bir şekilde yapılandırılması konusunda öğretmenlerin daha planlı ve sistemli hareket etmeleri gerektiğini ve okuma derslerinde çeşitli metin türlerinden sıklıkla yararlanıp kitabın kendisinin ciddi bir motivasyon unsuru haline getirilmesinin önemini vurgulamıştır. Benzer şekilde, Guthrie vd. (1993) öğretmenin öğrencileri okumaya yönlendirmesi, sınıf içinde yapılan okumalarda öğrencilere rehberlik etmesi öğrencilerin okuma miktarını arttırdığını vurgulamıştır. Bu nedenle öğretmenler derslerde kitaplar hakkında münazaralar yapabilir ve kitaplar hakkında sohbetler açabilir. Ayrıca öğretmenler okuduklarını öğrencilerle paylaşarak onları okumaya güdüleme yönünde önemli bir adım atmış olur. Güneş (2013) yaptığ1 araştırma sonucunda öğrencilerini okumaya güdüleyen öğretmenlerin, okuma alışkanlığı kazandırmada oldukça etkili olduklarını tespit etmiştir. Gökçe (2012) çalı̧̧masında, öğrencilerin kitap okuma alışkanlıklarının geliştirilmesi açısından, okulda düzenlenen okuma saatlerine uyulması, kitap okuma yarışması yapılması, okul/sınıf kütüphanesinde gerekli sayı ve yeterlikte kitap bulundurulması, çok kitap okuyan öğrencilerin ödüllendirilmesi ve okuma kitaplarının ücretsiz dağıtılmasının gerektiğini vurgulamaktadır. Arıcı (2005) ise okuma alışkanlığının geliştirilmesinde en etkili faktörün ögretmen olduğunu belirtmiştir. Bu sonuçtan yola çıkarak, okuma motivasyonunun artırılması ve okumanın alışkanlık haline gelmesinde öğretmenin son derece önemli bir etkisi olduğu söylenebilir. 
Bu çalışmada öğretmenin etkisi, öğrencileri okumaya yönlendirme ve teşvik etme bakımından olumlu görülürken, okumada rol model davranışları gösterme bakımından yeterli bulunmamıştır. Bu durum öğretmenlerin yeterince okuma alışkanlığına sahip olmamasından kaynaklanabilir.

$\mathrm{Bu}$ araştırmada öğrencilerin okuma motivasyonlarını etkileyen faktörlerden aile boyutu ile ilgili olarak öğrenciler ağırlıklı olarak ailelerinin "her zaman" kendilerini kitap okumaya teşvik ettikleri $(\% 55,37)$ ve kitap okudukları için "her zaman" kendilerini övdükleri $(\% 44,42)$, "her zaman" okuduklarını kendilerine anlatılmasını istedikleri $(\% 41,38)$, yeni çıkmış çeşitli okuma materyallerini "ara sıra" satın aldıkları $(\% 30,73)$ ve ailelerinin kendilerine "ara sıra" kitap armağan ettikleri $(\% 32,86)$ tespit edilmiştir.

Konu ile ilgili alan yazın incelendiğinde, Ülper (2011a) ilkokul öğrencilerinin aileleri tarafından "her zaman" okumaya teşvik edildiklerini ve övüldüklerini, ailelerinin kendilerine "sık sık" kitap önerdiğini ancak ailelerini okuduklarını anlatmalarını isterken "ender" olarak gördükleri tespit etmiştir. Bu durum, ailelerin etkin olmaktan çok, dolaylı olarak güdüleyici olmaya çalıştıkları şeklinde yorumlamıştır. Başka bir araştırmada öğrenci velilerinin, çocuklarının okuma alışkanlığını sadece okulda kazanabileceklerini düşündükleri tespit edilmiştir (Aş1lığlu, 2008). Gökçe (2012), Yurtbakan \& Erdoğan (2020) yaptıkları araştırma sonucunda, velilerin çoğunluğunun, çocuklarının kitap okumasını teşvik ettiğini ve okumaları için çeşitli kitaplar satın aldıklarını ortaya koymuşlardır. Benzer şekilde Guthrie vd. (1993) okuduklarını aileleri ile paylaşan öğrencilerin daha etkin bir biçimde kitap okuduklarını vurgulamıştır. Tosunoğlu'nun (2002) yaptı̆̆ araştırma sonucunda öğrenci velilerinin önemli bölümünün, çocuklarının "mutlaka okuması gerektiği”" yönünde $(\% 88,8)$ görüş belirttikleri tespit edilmiştir. Gök (2019) çocukların kitaplardan şekilleri, yeni isimleri ve renkleri öğrendikleri anlayışında olan öğretmen ve ailelerin onların iyi bir dinleyici ve konuşmacı olmasında önemli katkıları olacağını belirtmiştir. Başaran \& Ateş (2009) ailelerin çocuklarına hikaye okuma ve anlatma sıklığının onların okumaya ilişkin tutumları üzerinde oldukça etkili olduğu; Suna (2006) ise anne ve babası kitap okumaya zaman ayıran, ona sesli bir biçimde kitap okuyan, kitaplar hakkında sohbetler yapılan, ailesi tarafından kitap hediye edilen, evde ortak kararlaştırılan bir okuma saati olan çocukların, okuma ilgisi düzeylerinin olumlu yönde etkilendiği sonucuna ulaşmıştır.

Bununla beraber bazı çalışmalarda anne ve babaların çocuklarına boş zamanlarında okumak için kitap aldıkları (Bayis, 2010; Devrimci,1993; Gönen, Öncü \& Işıtan, 2004; Keleş, 2006) tespit edilirken, İşcan, Arıkan \& Küçükaydın'ın (2013) yaptığı çalışmada, öğrencilerin büyük bir kısmı ebeveynlerin kendilerine kitap okumadıklarını vurgulamışlardır. Yine bazı çalışmaların sonuçları (Aslan \& Harput, 2017; Duran \& Sezgin, 2012) velilerin okuma konusunda çocuklarına iyi bir rol model olamadıklarını göstermektedir.

Yalınkılıç'ın (2017) çalışmasında öğrenciler, ebeveynlerini ender olarak kitap okurken gördüklerini ve ailelerinden hediye olarak ara sira kitap aldıklarını belirtilirken, Yılmaz (2004) ebeveynlerin okuma konusunda duyarlı davranmadıkları sonucuna ulaşmıştır. Toplumsal, ekonomik, kültürel, ruhsal birçok boyuta sahip okuma alışkanlığının çocukluk döneminde kazandırılmasında en önemli görev aile ve okula düşmektedir (Devrimci, 1993). Okumayı çabuk öğrenen okul hayatı boyunca iyi okur olan ögrenciler üzerinde yapılan incelemede, bu çocuklara küçük yaşlardan itibaren kitap okunduğu ve zevk için okuyan yetişkin ve ebeveynleri örnek aldıkları tespit edilmiştir (Gönen \& Devrimci, 1993). Yılmaz \& Çalışkan (2017) ve Katrancı (2015) yaptıkları araştırmanın sonucunda, okuma motivasyonu yüksek öğrencilerin, motivasyon kaynağı olarak ilk sıralarda aile ile ilgili faktörleri gösterdiklerini belirtmişlerdir. Benzer şekilde Kurnaz \& Yıldız (2015) ebeveynin kitap okuma konusundaki çabalarının ve model davranışlarının çocukların kitap okuma motivasyonları üzerinde önemli katkısı olduğunu ortaya koymuştur. Yalınkılıç (2017) ise çalışmasında; ailelerin okuma motivasyonu ve okuma alışkanlığı süreçlerinde etkin rol oynamaları gerektiğini, çocuklarına örnek olmanın dışında okumaya teşvik etme, farklı okuma materyallerini sunma konularında daha dikkatli davranmaları gerektiği belirtilmiştir. Bu verilerden yola çıkılarak, okuma motivasyonu kazandırmada ailelerin çocuklarına yeterince rol model olmadıkları ancak belli düzeyde teşvik ettikleri söylenebilir. Dolayısıyla alanda yapılan çalışmaların bu araştırmanın sonucunu destekler nitelikte olduğu söylenebilir.

$\mathrm{Bu}$ araştırmada öğrenciler arkadaşlarını ağırlıklı olarak, "her zaman" kitap okurken gördükleri $(\% 41,18)$, okudukları kitapları arkadaşları ile "her zaman" değiştikleri $(\% 39,15)$, kitap okudukları için arkadaşlarının "hiçbir zaman" kendilerini övmedikleri $(\% 35,60)$ ve "hiçbir zaman" kitap armağan etmedikleri $(\% 36,81)$ tespit edilmiştir. İlgili literatüre bakıldığında, Ülper (2011a) yaptığı çalışmada 
ilkokul öğrencilerinin akranlarını "her zaman" kitap okurken gördüklerini, okunan kitapların değişimini "ara sıra" yaptıklarını belirtmişlerdir. Yalınkılıç (2017) çalışmasında arkadaş boyutu açısından ilkokul öğrencileri en çok arkadaşlarını kitap okurken görürken, arkadaş çevrelerinde kitabı bir paylaşım unsuru haline getiremedikleri sonucuna ulaşmıştır. Balcı'nın (2009) araştırmasında öğrencilere arkadaşlarıyla kitap alış-verişi yapıp yapmadıkları sorusuna \%73,5 oranında "evet" cevabı verilirken, Dökmen'in (1994) farklı öğrenim düzeyindeki öğrenciler üzerinde gerçekleştirdiği araştırmada kitaba ulaşmada \%78 ile en yüksek oran "arkadaşlardan ödünç alma" yönteminin kullanıldığg tespit edilmiştir. Balcı'nın (2009) 8. sınıf öğrencileri üzerinde yaptığı araştırmada, öğrencilerin kitaba ulaşmada kullandıkları önemli yollardan biri olan "arkadaşlarından ödünç alma" oranı \%18,5 olarak belirlenmiştir. Bayis (2010) ve Keleş'in (2006) tarafından yapılan araştırma sonuçları da öğrencilerin arkadaşlarıyla değiştirmediklerini göstermektedir. Ayrıca İşcan, Arıkan \& Küçükaydın (2013) öğrencilerin \%56'sının okudukları kitabı kendi aralarında tartışmadıklarını tespit etmiştir. Benzer şekilde ilgili literatürde öğrenciler arkadaşlarını kitap okurken görürlerken; okudukları kitapları değiş tokuş yapma konusunda farklı sonuçlar ortaya çıkmıştır. Suna (2006) yaptığı çalışmada, öğrenciler arkadaşları ile birlikte okuduğu kitaplar hakkında sohbetler yapıyorsa ve arkadaşları ile kitap değiş tokuşu yapıyorsa, öğrencilerin okuma ilgisinin olumlu yönde etkilendiğini belirtirken; Guthrie vd. (1993) okuduklarını akranlarıyla paylaşan öğrencilerin daha etkin bir biçimde okudukları vurgulanmıştır. Ayrıca Ülper (2011b) araştırmasında kitap armağan edilmesinin okumaya güdüleyici etkisine belirgin bir biçimde dikkat çekmiştir. Bu bağlamda alan yazındaki araştırma bulgularıyla mevcut araştırma bulgularının birbirini destekler nitelikte olduğu söylenebilir. Nelson \& DeBacker (2008) yaptığı araştırmada iyi arkadaşlık ilişkisine sahip olan ve sınıf arkadaşları tarafından sevilen/sayılan öğrencilerin başarı motivasyonlarının daha yüksek olduğu sonucuna ulaşılmıştır. Doğal olarak bu durum okuma motivasyonuna da yansımaktadır. Öğrencilerin arkadaşlarını okurken görmeleri ve okuduklarını paylaşmalarının okumaya güdelemeye etkisi olabilir.

$\mathrm{Bu}$ araştırmada öğrenciler, kendilerine okumaları için tavsiye edilen kitapları, "her zaman" ilgi alanlarına uygun buldukları $(\% 42,90)$, "her zaman" düzeylerine uygun buldukları $(\% 46,75)$, "her zaman" yararlı buldukları $(\% 51,32)$, "her zaman" özgürce seçtikleri $(\% 57)$ ve "her zaman" eğlenceli bulduklarını $(\% 56,39)$ ifade etmişlerdir. Kitap alt boyutu içerisinde yer alan maddelere ilişkin olarak öğrencilerin "her zaman" düzeyinde görüş bildirmeleri, kitapların, öğrencilerin okuma motivasyonlarını her zaman etkiledikleri; başka bir deyişle kitaba ilişkin etmenlerin öğrencileri "her zaman" okumaya güdülediği şeklinde yorumlanabilir. Bu durum, kitapların özellikleri ve kitap alırken tercihlerinin dikkate alınması öğrencileri okumaya yöneltmek açısından ne denli önemli olduğunu göstermektedir. Alan yazında bu bulguyu destekleyen çeşitli çalışmalara rastlanmaktadır. Suna'nın (2006) araştırmasında kitap alırken tercihlerine önem verilen, anne ya da babası kitap alırken düşünceleri sorulan çocukların okumaya ilgi düzeylerinin olumlu yönde etkilendiği görülmüştür. Edmunds \& Bauserman (2006) ve Katrancı (2015) çocukların kitapları kendilerinin seçmesinin ve hikâye kitaplarında çocukları heyecanlandıran unsurların çocukların kişisel ilgileri ve kitapların özelliklerine bağlı olduğu belirtilmiştir. Temel okuma-yazma becerilerinin kazanılmaya başlandığ1 ilkokul döneminde, Sever'e (2007) göre çocukların okudukları kitapların nitelikleri, onların iyi okur olmaları bakımından önem arzetmektedir. Tosunoğlu'nun (2002) yaptı̆̆ı araştırma sonucunda öğrencilerin çoğunlukla macera türü $(\% 64,4)$ kitaplardan hoşlandığını saptamıştır. Ayrıca, öğrencilerin kitap seçimindeki en önemli etmenin kitabın konusu olduğunu vurgulamıştır. Benzer şekilde, Yıldız (2010) öğrencilerin okul dışında ilgi ve merak duydukları yayınları okumaya önem verdikleri sonucuna ulaşmıştır. Gökçe (2012) yaptığı araştırma sonucunda öğrencilerin sırasıyla en çok macera, bilim-kurgu, mizah ve polisiye içerikli kitapları okuduklarını ve sırasıyla kitap okumaya derslerin yoğunluğu, TV izleme, bilgisayar ve ev işlerinin engel olduğunu belirtmiştir. Aksoy \& Öztürk (2018) ise öğrencilerin \% 40,5'inin çevresinde ilgisini çekecek konularda kitap, dergi vb. bulamadığını tespit etmiştir. Tüm bu çalışmalar araştırma sonuçlarını destekler niteliktedir. Şöyle ki, özellikle öğrencilerin ilgi alanlarına uygun kitap seçmelerine imkân sağlanması öğrenciler açısından son derece önemlidir. Öğrencilerin okumak istedikleri kitapları ilgi alanlarına göre belirlemelerinin ardında bilişsel bir gerçeklik bulunmaktadır. Kişisel ilgi, öğrenmede ve bilişsel işlevleri yerine getirmede kolaylaştırıcı bir etkiye sahiptir. Dolayısıyla da metindeki bilgiyi daha etkili ve daha hızlı bir biçimde kodlamayı sağlamaktadır. Bu bakımdan öğrenciler açısından ilginç olan öyküler, kavrama açısından daha kolay ve daha az dikkat gerektiren türden olmalıdır (Ülper, 2011b). Aynı şekilde, Hidi (1990) ve Mckool'un 
(2007) araştırmalarında öğrencilere, ilgi alanlarına uyan kitap seçme olanağının sunulması durumunda pek çok öğrencinin okumaya güdüleneceği vurgulanmaktadır.

\section{Öneriler}

Araştırma sonuçlardan yola çıkılarak şu önerilerde bulunulabilir:

1. Çocukların hayatlarının en önemli yıllarını geçirdiği okulun, çocuğa okumayı sevdirme, okumaya yönlendirme ve okuma motivasyonu kazandırma konularında görevi ve sorumluluğu oldukça büyüktür. Bu bakımdan öğretmenler bu konu üzerinde daha ciddî durmalı ve bu konuda yeni etkinlikler (derslerde kitaplar hakkında münazaralar yapma, kitaplar hakkında sohbetler etme, okuduklarını öğrencilerle paylaşma vb.) geliştirebilmelidir.

2. Okuma alışkanlığının temellerinin ailede atıldığına göre ebeveynler, çocuklarına bu alışkanlığı kazandırma ve onları okumaya güdüleme yönünde bilinçlendirilmelidir. Ayrıca bu amaçla uzmanlarca ailelere gerekli eğitim desteği sağlanmalı ve çocuklara okuma alışkanlığı kazandırılması amacıyla düzenlenen etkinliklere katılımı sağlanmalıdır.

3. Öğrencileri okumaya güdülemek için öğretmen ve aileler onlara kitap hediye etmeli, rol model olmalı, güvenmeli ve özerklik tanımalı; öğretmenler ve aileler tarafından çocuklara ilgi alanlarına uygun ve eğlendirici kitaplar sunulmalı, arkadaş çevresinin son derece önemli olduğu düşüncesinden hareketle arkadaş seçimi konusunda onlara yardımcı olmalıdırlar.

4. Aynı amaca dönük araştırmalar farklı sınıf düzeylerinde, başka illerde hatta imkânlar ölçüsünde Türkiye genelinde yapılmalı; yeni araştırmalarda yarı yapılandırılmış görüşme yöntemine yer verilmelidir. Hatta imkânlar ölçüsünde nicel ve nitel araştırma teknikleri birlikte kullanılmalıdır.

\section{Kaynakça}

Aksoy, E. \& Öztürk, D. S. (2018). Öğrencilerdeki okuma alışkanlığının öğrenci ve öğretmen görüşlerine göre belirlenmesi. Türkiye Sosyal Araştırmalar Dergisi, 22(1), 143-184.

Aktaş, E. \& Çankal, A.O. (2019). Akıcı okuma stratejilerinin 4. sınıf türkçe derslerinde okuduğunu anlama becerisine ve okuma motivasyonuna etkisi. ZfWT 11 (1), 85-114.

Akyol, H. \& Çoban Sural, Ü. (2021). Developing Reading, Reading Comprehension and Motivation: An Action Research Study. Education and Science. 46(205), 69-92.

Arıcı, A.F. (2005). İlköğretim ikinci kademe öğrencilerinin okuma durumları. (Yayımlanmamış doktora tezi). Atatürk Üniversitesi Sosyal Bilimler Enstitüsü. Erzurum.

Aslan, Y. \& Harput, M.B. (2017). Çocuk eğitimi ve kitap okuma alışkanlığı üzerindeki aile etkisi: susanna tamaro "kitaplardan korkan çocuk" örneği. Uluslararası Çocuk Edebiyatı ve Eğitim Araştırmaları Dergisi,1, 17-30.

Aş1lığlu, B. (2008). Bilişsel öğrenmeler için eleştirel okumanın önemi ve onu geliştirme yolları. Dicle Üniversitesi Ziya Gökalp Eğitim Fakültesi Dergisi, 10, 1-11.

Baki, Y. (2019). Türkçe öğretmeni adaylarının üst bilişsel okuma stratejilerinin okuma motivasyonu üzerindeki etkisindeki sınıf düzeyinin ve cinsiyetin rolü. Marmara Üniversitesi Atatürk Ĕ̈itim Fakültesi Ĕ̈itim Bilimleri Dergisi, 50, 15-42. DOI: 10.15285/maruaebd.586837

Balcı, A. (2009). İlköğretim sekizinci sınıf öğrencilerinin okuma alışkanlık ve ilgileri üzerine bir araştırma. (Yayımlanmamış doktora tezi). Gazi Üniversitesi Eğitim Bilimleri Enstitüsü. Ankara.

Bamberger, R. (1990). Okuma alışkanlığını geliştirme. (B. Çapar, Çev.). Ankara: Kültür Bakanlığı.

Başaran, M. \& Ateş, S. (2009). İlköğretim beşinci sınıf öğrencilerinin okumaya ilişkin tutumlarının incelenmesi. Gazi Ĕ̈itim Fakültesi Dergisi, 29 (1), 73-92.

Batmaz, O. \& Erdoğan, Ö. (2019). İlkokul 4. sınıf öğrencilerinin okuma motivasyonları ile okuduğunu anlama becerileri arasındaki ilişki ve bu konuya yönelik öğretmen görüşleri. Elektronik Sosyal Bilimler Dergisi, 18(71),1429-1449.

Bayis, S. (2010). 4., 5., 6., 7. Sınıf öğrencilerinin kitap okuma ve kütüphane kullanım alışkanlıklarının incelenmesi. (Yayımlanmamış yüksek lisans tezi). Hacettepe Üniversitesi Sağlık Bilimleri Enstitüsü. Ankara. 
Boerma, I. E., Mol, S. E. \& Jolles, J. (2016). Teacher perceptions affect boys' and girls' reading motivation differently. Reading Psychology, 37(4), 547-569.

Büyüköztürk, Ş., Kılıç Çakmak, E., Akgün, Ö. E., Karadeniz, Ş. \& Demirel F. (2008). Bilimsel araştırma yöntemleri. Pegem Akademi.

Coşkun, E. (2006). Lise öğrencilerinin okuma hızı ve anlama düzeyleri üzerine bir araştırma. Milli Ĕgitim, 172, 29-39.

Deci, E., Koestner, R., \& Ryan, R. (2001). Extrinsic rewards and intrinsic motivation in education: Reconsidered once again. Review of Educational Research, 71(1),1-27. doi:10.1006/ceps.1999.1020

Devrimci, H. (1993). İlkokul 5. sınıf çocuklarında okuma alışkanlığının incelenmesi. (Yayımlanmamış Yüksek lisans tezi). Hacettepe Üniversitesi Sağlık Bilimleri Enstitüsü. Ankara.

Dökmen, Ü. (1994). Okuma becerisi, ilgisi ve alışkanlı̆̆ üzerine psiko-sosyal bir araştırma. Milli Eğitim Bakanlığı Yayınları. 652. Bilim Kültür Eserleri Dizisi., 2531.

Duran, E. \& Sezgin, B. (2012). İlköğretim 4 ve 5. sınıf öğrencilerinin okuma alışkanlıklarının ve ilgilerinin belirlenmesi. International Periodical For the Languages, Literature and History of Turkish or Turkic Volume 7(4), 1649-1662.

Edmunds, K. M. \& Bauserman, K. L. (2006). What teachers can learn about reading motivation through conversations with children. The Reading Teacher, 59 (5), 414-424. doi:10.1598/RT.59.5.1

Gök, S. (2019). Başlangıç düzeyi okuyucularının okuma motivasyonu üzerinde aile okuma inançlarının etkisi. (Yayımlanmamış yüksek lisans tezi). Sakarya Üniversitesi Eğitim Bilimleri Enstitüsü. Sakarya.

Gökçe, E. (2012). İlköğretim öğrencilerinin kitap okuma alışkanlıkları. S. Sever ve diğerleri (Yay. haz.). 3. Ulusal Çocuk ve Gençlik Edebiyatı Sempozyumu içinde (s. 825-833). Ankara: Ankara Üniversitesi Çocuk ve Gençlik Edebiyatı Uygulama ve Araştırma Merkezi.

Gönen, M. \& Devrimci H. (1993). 9. Okulöncesi eğitimi ve yaygınlaştırılması semineri. Ya-Pa Yayınlar1.

Gönen, M., Öncü, E. \& Işıtan, S. (2004). İlköğretim 5. 6. ve 7. sınıf öğrencilerinin okuma alışkanlıklarının incelenmesi. Milli Eğitim Dergisi, 164. Erişim adresi: https://dhgm.meb.gov.tr/yayimlar/dergiler/Milli_Egitim_Dergisi/164/

Guthrie, J. T., Schafer, W., Wang, Y. Y. \& Afflerbach, P. (1993). Influences of intruction on amount of reading: an empirical exploration of social, cognitive and intructional indicators. National Reading Research Center, 3, 9-36. Erişim adresi: https://files.eric.ed.gov/ fulltext/ED359503.pdf

Güneş, A. (2013). Türkiye'de köy ilköğretim okul kütüphaneleri ve okuma alışkanlığı: kastamonu ili örneği. (Yayımlanmamış yüksek lisans tezi). Ankara Üniversitesi Sosyal Bilimler Enstitüsü. Ankara.

Güneş, F. (2007). Türkçe ögrretimi ve zihinsel yapılandırma. Nobel Yayın Dağıtım.

Harris, A. J. \& Sipay, E. R. (1947). How to increase reading ability, a guide to individualized and remedial methods. Longman.

Hidi, S. (1990). Interest and 1ts contribution as a mental resource for learning. Review of Educational Research, 60, 549-571. Erişim adresi: http://citeseerx.ist.psu.edu/viewdoc/summary?doi=10.1.1.938.8376.

Hidi, S. (2000). An interest researcher's perspective: the effects of extrinsic and intrinsic factors on motivation. C. Sansoe ve J. M. Harackiewicz. (Ed), Intrinsic and Extrinsic Motivation: The Research for optimal motivation and performance (s. 309-339) içinde. Academic Press.

İskender, H. (2013). Türkçe öğretmenlerinin okuma ilgileri ve öğrencilere okuma alışkanlığ1 kazandırmaya yönelik etkinlikleri üzerine bir araştırma (Trabzon ili örneği). (Yayımlanmamış Yüksek Lisans Tezi). Karadeniz Teknik Üniversitesi Eğitim Bilimleri Enstitüsü. Trabzon.

İşcan, A., Arıkan, İ. B. \& Küçükaydın, M. A. (2013). İlköğretim ikinci kademe öğrencilerin kitap okuma alışkanlıkları ve okumaya ilişkin tutumları. Uluslararası Avrasya Sosyal Bilimler Dergisi, 4(11), 1-16.

Karakullukcu, N. \& Çelik, Y. (2020). İlkokul öğrencilerine kitap okuma alışkanlığı kazandırmada sınıf öğretmenlerinin rolü. Adnan Menderes Üniversitesi Ĕ̈itim Fakültesi Eğitim Bilimleri Dergisi, $11(2), 1-14$. 
Karasar, N. (2012). Bilimsel araştırma yöntemi. (23. Baskı). Nobel Yayın Dağıtım.

Karatay, H., Külah, E. \& Kaya, S. (2020). Okuma alışkanlığını geliştirme yöntem, teknik ve modelleri. Okuma Yazma Eğitimi Araştırmaları, 8(1), 89-107.

Katranc1, M. (2015). İlkokul dördüncü sınıf öğrencilerinin kitap okuma motivasyonlarının incelenmesi. Ana Dili Eğitimi Dergisi, 3(2), 49-62.

Keleş, Ö. (2006). İlköğretim 4. ve 5. sınıf öğrencilerinde kitap okuma alışkanlığının incelenmesi. (Yayımlanmamış yüksek lisans tezi). Gazi Üniversitesi Eğitim Bilimleri Enstitüsü. Ankara.

Kızgın, A. \& Baştuğ, M. (2020). Okuma motivasyonu ve okuduğunu anlama becerisinin akademik başarıyı yordama düzeyi. Dil Eğitimi ve Araştırmaları Dergisi, 6(2), 601-612, Doi: $10.31464 /$ jlere. 767022

Kurnaz, H. \& Yıldız, N. (2015). Ortaokul öğrencilerinin okuma motivasyonlarının çeşitli değişkenlere göre değerlendirilmesi. Türkiye Sosyal Araștırmalar Dergisi, 19(3), 53-70.

Kuşdemir, Y. \& Güneş, F. (2015). Doğrudan öğretim modelinin okuduğunu anlama becerilerine etkisi. Mehmet Akif Ersoy Üniversitesi Eğitim Fakültesi Dergisi, 1(32), 86-113.

McKool, S. S. (2007). Factors that influence the decision to read: an investigation of fifth grade students' out-of-school reading habits. Reading improvement, 22, 111-131.

Millı̂ Eğitim Bakanlığı. (2005). İlköğretim Türkçe dersi programı ve kılavuzu (6, 7, 8. Sinıflar). MEB Yayınları.

MEB. (2009). İlköğretim (1-5. Sinıflar) Türkçe öğretim programı. MEB Yayınları.

MEB. (2010a). PISA 2006 Projesi ulusal nihai raporu. Eğitimi Araştırma ve Geliştirme Dairesi Başkanlığ $1, \quad$ Erişim adresi: http://pisa.meb.gov.tr/wp content/uploads/2013/07/PISA2006-Ulusal-Nihai-

MEB. (2010b). PISA 2009 ulusal ön raporu. Eğitimi Araştırma ve Geliştirme Dairesi Başkanlığı. Erişim adresi: http://pisa.meb.gov.tr/wp- content/uploads/2013/07/PISA-2009-Ulusal-OnRapor.pdf

MEB. (2015), PISA 2012 ulusal nihai raporu. Eğitimi Araştırma ve Geliştirme Dairesi Başkanlığı, Erişim adresi: https://drive.google.com/file/d/0B2wxMX5xMcnhaGtnV2x6YWsyY2c/view

MEB. (2018). Tebliğler dergisi (Say1: 2735-Ek). Erişim adresi: http://tebligler.meb.gov.tr/index.php/tuem-sayilar/viewcategory/86-

MEB. (2019a). PISA 2018 Türkiye ön raporu. Erişim adresi: http://www.meb.gov.tr/meb_iys_dosyalar/2019_12/03105347_PISA_2018_Turkiye_On_Rapo ru.pdf.

MEB. (2019b). Türkçe dersi (1-8. Sinıflar) öğretim programı. MEB Yayınları.

Monteiro, V. (2013). Promoting reading motivation by reading together. Reading Psychology, 34, 301 335.

Nelson, R. M., \& DeBacker, T. (2008). Achievement motivation in adolescents: The role of peer climate and best friends. The Journal of Experimental Education, 76(2), 170-189.

Öz, M. F. (2011). Uygulamalı Türkçe ögrretimi. Anı Yayıncılık.

Özdemir, E. (2007). Eleştirel okuma. (7. Baskı). Bilgi Yayıncılık.

Özerbaş, M. A. \& Öztürk, Y. (2017). Türkçe dersinde dijital hikâye kullanımının akademik başarı, motivasyon ve kalıc1lık üzerinde etkisi. TÜBAV Bilim 10 (2), 102-110.

Öztürk, E. \& Aydemir, Z. (2012). Başlangıç düzeyi okuyucularının okuma motivasyonlarının, günlük kitap okuma süreleri ve ailenin okuma durumuna göre değerlendirilmesi. Kastamonu Eğitim Dergisi, 21(3),1105-1116.

Sanc1, D. (2002). İlköğretim 6. sınıf öğrencilerinin toplumsal, ekonomik ve kültürel durumlarının okuma motivasyonuna etkisi. (Yayımlanmamış yüksek lisans tezi). Atatürk Üniversitesi Sosyal Bilimler Enstitüsü, Ankara.

Schaffner, E., Schiefele, U., \& Ulferts, H. (2013). Reading amount as a modiator of the effests of intrinsic and extrinsic reading motivation on reading comrehension. Reading Research Quarterly, 48(4), 369-385.

Schunk, D. H. (2011). Motivasyon (E.T. Üzümcü ve L. Tuay, Çev.). M. Şahin, (Ed.). Öğrenme teorileri: Eğitimsel bir bakışla (s. 452-511) içinde. Nobel Yayın Dağıtım.

Sever, S. (2007). Türkçe ögrretimi ve tam ögrrenme. Anı Yayıncılık. 
Suna, Ç. (2006). İlköğretim öğrencilerinin okuma ilgi ve alışkanlıklarını etkileyen etmenlerin analitik olarak incelenmesi ve değerlendirilmesi. (Yayımlanmamış yüksek lisans tezi). Anadolu Üniversitesi Eğitim Bilimleri Enstitüsü. Eskişehir.

Sünbül, A. M., Yılmaz, E., Demirer, V., Ceran, D., Işık, A., Çintaş, D., M., Çalışkan, M. \& Alan, S. (2010). Illkögretim ögrencileri kitap okuma alışkanlıkları: Konya ili araştırma raporu (5-6-78. siniflar). Selçuk Üniversitesi Matbaası.

Tekgül, K. (2013). İdareci ve öğretmenlerin öğrencilerde kitap okuma alışkanlığının geliştirilmesine yönelik düşüncelerinin incelenmesi. (Yayımlanmamış yüksek lisans tezi). Yeditepe Üniversitesi Sosyal Bilimler Enstitüsü. İstanbul.

Tosunoğlu, M. (2002). Türkçe öğretiminde okuma alışkanlıkları ve çocukların okuma eğilimleri. Türk Dili Dergisi, 609, 547-563.

Tunç, T. C. (2018). Sınıf öğretmenlerinin okumaya karşı tutumları ve okuma alışkanlıkları. (Yayımlanmamış yüksek lisans tezi). Gazi Üniversitesi Eğitim Bilimleri Enstitüsü. Ankara.

Ülper, H. (2011a). Öğrencilerin, okumaya isteklendirici etmenlerle karşılaşma durumu: öğretmen, aile, arkadaş ve kitap boyutları üzerine bir araştırma. Buca Eğitim Fakültesi Dergisi, (30), 221-237.

Ülper, H. (2011b). Öğrenci açısından okumaya güdüleyici etmenler. Kuram ve Uygulamada Eğitim Bilimleri Dergisi, 11(2), 941-960.

Wigfield, A., Gladstone, J. R. ve Turci, L. (2016). Beyond cognition: Reading motivation and reading comprehension. Child Development Perspectives, 10(3), 190-195.

Yalınkılıç; K. (2017). Öğrencilerin okumaya karşı güdüleyici etmenlerle karşılaşma durumları ve okuma alışkanlıklarına ilişkin görünümleri. Researcher: Social Science Studies, 5(4), 423-434. doi:10.18301/rss.509.

Yamaç, A. \& Çeliktürk Sezgin, Z. (2018). İlkokul dördüncü sınıf öğrencilerinin okuma kaygıları, akıcılıkları, motivasyonları ve okuduğunu anlamaları arasındaki ilişkiler. Eğitim ve Bilim, 43(194), 225-243.

Yıldız, M. (2010). İlköğretim 5. sınıf öğrencilerinin okuduğunu anlama, okuma motivasyonu ve okuma alışkanlıkları arasındaki ilişki. (Yayımlanmamış doktora tezi). Gazi Üniversitesi Eğitim Bilimleri Enstitüsü. Ankara.

Yıldız, M. \& Akyol, H. (2011) İlköğretim 5. sınıf öğrencilerinin okuduğunu anlama, okuma motivasyonu ve okuma alışkanlıkları arasındaki ilişki. Gazi Eğitim Fakültesi Dergisi, 31(3), 793-815.

Yılmaz, B. (2004). Öğrencilerin okuma ve kütüphane kullanma alışkanlıklarında ebeveynlerin duyarlılı̆̆ . Bilgi Dünyası Dergisi, 5(2), 115-136.

Yılmaz C. \& Çalıșkan, M. (2017). Yatılı ortaokul öğrencilerinin okuma motivasyonlarının incelenmesi. International Periodical for the Languages, Literature and History of Turkish or Turkic, 12(33), 573-588.

Yılmaz, M. \& Ertem, İ.S. (2020). İlkokul öğrencilerinin okuma alışkanlıklarının çeşitli değişkenler açısından incelenmesi. Journal Of Social, Humanities and Administrative Sciences, 6(34):2210-2219

Yurtbakan, E. \& Erdoğan, T. (2020). İlkokul 4. sınıf öğrencilerinin okuma alışkanlıklarının belirlenmesi: bir karma yöntem. Ana Dili Eğitimi Dergisi, 8(2), 240-257.

\section{Extended Abstract}

\section{Introduction}

Just as an activating mechanism is needed in the education process as well as every stage of life, an activating mechanism is also needed for reading. This mechanism is motivation. Motivated students take responsibility for reading even if they are not asked to, read books related to their interests, have various interests. These students do not give up and try harder when they face difficulties. The motivation to read has four basic elements. These are the teacher, the family, the friend and the book itself. In addition to the importance and effect of reading motivation in gaining reading habits, there are various researches examining the relationship between reading motivation and reading comprehension. However, researches on the factors affecting primary school level and reading motivation are very limited. For this reason, it is expected that this research, conducted on a large 
group of participants, in order to determine the factors affecting the reading motivation of primary school students and to make some suggestions on this subject, will contribute to the related researches.

\section{Method}

In the research survey model has been used, which is one of the descriptive research methods. The universe of the research consists of 4 th grade students studying in primary schools affiliated to the Ministry of National Education. The sample of the research consists of 4th grade students attending primary school affiliated to Samsun Provincial Directorate of National Education in 2013-2014 academic year. Since the research universe is very large, the sample was determined, and in this context, the sample was chosen by proportional cluster sampling. In the 2013-2014 academic year when the research was conducted, the total number of 4th grade students attending primary school in schools affiliated to Samsun Provincial Directorate of National Education is 17933. Considering the 95\% confidence level and tolerable error rate regarding the adequacy of the sample to represent the universe, 644 people are sufficient for a population of 20,000 people (Büyüköztürk et al., 2008). The "Questionnaire to determine the opinions of primary school students about the factors that motivate reading" scale developed by Ülper (2011a) was used in the research. The scale concist of 35-item. The schools attended for the application were randomly selected.

\section{Discussion and Conclusions}

In this research, students mostly stated that they saw their teachers "sometimes" while reading a book (38.85\%), that the teachers "always" recommended the books they read (\%32.25), that they "always watched" whether or not the students read a book (\% 60.85), and the teachers praise the students who read books "always" (\%46.04). According to data, teachers are not enough models to students at reading, but they encourage students to read. It can be said that the studies in the literature support these results. In this study, while the teacher's influence was positive in terms of directing and encouraging students to read, it was not found sufficient in terms of showing role model behaviors in reading. This stuation is related to the fact that teachers do not have enough the reading habits. Regarding the family dimension, which is one of the factors affecting students' reading motivation, the students stated that their families "always" encouraged them to read books (\%55.37), "always" praised themselves for reading books (\%44.42). According to the research findings, it is understood that the families of the students do not share what they read with their children, they rarely see their families reading a book, the families occasionally give books as gifts, the families recommend the books they read, want to told about the books they read and the reading hours are determined at home. It can be said that the studies carried out in the field support this result. In this study, the most of the students stated that they "always" see their friends reading a book (\%41.18), that they "always" change the books they read with their friends (\%39.15), that their friends "never" praise themselves for reading a book (\%35.60). It can be said that the research findings in the literature support these findings. In addition, it was concluded that the students found the recommended books to be suitable for their interests and levels, found the books generally useful, chose their books independently and found them entertaining. According to the results of the research, determined that while the reading motivation of the students was more frequently affected by the teachers and the books, it was less affected by the family and friends. In line with these findings, it can be said that students' motivation to read books is generally at a moderate level. In the literature, there are various studies supporting these results. ${ }^{i}$

\footnotetext{
' Bu makaleye yazarlar eşit oranda katkıda bulunmuştur.
} 